\title{
God, the Christ and the Spirit in William P. Young's bestseller The shack Seen from a Pauline and Johannine Perspective
}

Author:

Andries G. van Aarde ${ }^{1}$

\section{Affiliation: \\ ${ }^{1}$ Faculty of Theology, \\ University of Pretoria, South Africa}

\section{Correspondence to:}

Andries G. van Aarde

e-mail:

andries.vanaarde@up.ac.za

\section{Postal address:}

Faculty of Theology,

University of Pretoria

Lynnwood Road 0083

Hatfield, South Africa

\section{Keywords:}

William P. Young;

The shack; public theology;

Trinity; postliberal

exegesis; mysticism

\section{Dates:}

Received: 01 July 2009

Accepted: 17 Aug. 2009

Published: 04 Nov. 2009

How to cite this article:

Van Aarde, A., 2009, 'God, the Christ and the Spirit in William P. Young's bestseller The shack seen from a Pauline and Johannine perspective', HTS Teologiese Studies/ Theological Studies 65(1), Art. \#305, 9 pages. DOI: 10.4102/v65i1.305

\section{This article is available}

at:

http://www.hts.org.za

\section{Note:}

This article is a reworked version of a paper presented at the Joint Conference of Academic Societies, Stellenbosch University, 22-26 June 2009. Dr Andries G. van Aarde is Honorary Professor of the Faculty of Theology, University of Pretoria, South Africa.

\section{(C) 2009. The Authors.} Licensee: OpenJournals Publishing. This work is licensed under the Creative Commons Attribution License.

\section{ABSTRACT}

Among its more than a million readers, The shack has empowered traditionalists and seekers among Christian spirituals but has also been condemned for patripassionism and modalism. This article consists mainly of two sections. The first section considers the issue of reviewers of The shack often assessing its religious legitimacy and the value of its message by means of critically questioning its adherence to texts in the Christian Bible. The second section focuses on the accusation that, dogmatically seen, The shack's narrative point of view is heresy, especially because of its nonstandard view of Christian dogma with regard to God Triune. The aim of the article is to argue that a great deal of commonality exists between the author of The shack and both Pauline and Johannine mysticism. With regard to their God talk, the author and these biblical writers express more of a present immanent communion with the transcendental God than an expectancy of authenticity that still lies in the future and exists outside humankind's immanent time and space. It is as if they draw the end time into the sphere of the here and now by passionately talking about communion with God as a process of the future, inhaled by the present. By doing so, the God-threesome meet wounded humankind in a 'shack', not in the 'church' as such or 'Scripture' as such as if God could be placed in a box.

\section{INTRODUCTION}

Central to the must-read bestseller The shack is the role of the Trinity in the form of three characters in one. Theologians reflecting on this book identify the 'emerging Christianity' movement as a probable influence on the author's theology. The God-threesome who meet wounded humankind in a shackand not in the church - differ from what Orthodoxy teaches on the personae of the Triune God, so it is said. In the book, the hands of God 'the Father' bear the marks of nails and 'He' is characterised as an African-American woman. Jesus Christ is characterised as a playful, smiling, Middle-Eastern carpenter. The Spirit is portrayed as an Asian woman, described as 'created being', 'action', 'breathing of life' and as 'Jesus' spirit'.

Far more than a million copies of The shack have been sold since its publication. ${ }^{1}$ The shack has empowered traditionalists and seekers among Christian spirituals (Olson 2009), but has also been condemned. A typical criticism is to disregard it as 'emergent heresy'. ${ }^{2}$ Among various ancient conceptualisations of God that were considered as heresies with regard to the orthodox dogma about the Holy Trinity were patripassionism and modalism, blasphemies that The shack allegedly advocates (Gilley 2008). Tertullianus (ca. 160-ca. $220 \mathrm{CE}$ ), anglicised as Tertullian, was the first theologian who used the term trinitas (Trinity) (Bethune-Baker 1903:440-442). In Tertullian's Against Praxeas (Evans 1948), he rejected Praxeas's view that the Father died on the cross (Tertullian [1985]). To the 'church fathers', such a view amounts to a paradox, 'modalism', which implies that the Father and the Son are the same person. Sabellius (of Pentapolis, Libya) claimed that the apostles taught modalism (Rush 1980:10). However, both Praxeas and Sabellius were banned by the Orthodox church (Moreschini \& Norelli 2005a:337-338). Modalism's unacceptability lies in the presumption that 'being father', 'being son' and 'being spirit' imply three equal modes of God's ontic Being. The Christians' God should rather be considered as having three separate personae with a hierarchical structure in each persona's relationship to the other, with God the Father being at the top and the Son being subserviently obedient to his suffering filial role, while the Spirit's status is again one step down, since the Spirit came forth first from the Father and then from the Son. Patripassionism's unacceptability lies in 'God the Father' sharing the suffering of 'God the Son'.

The shack's author, Young (2007), was not unaware of the accusation of being disrespectful towards the above-mentioned theism. Classical theism affirms the existence of a transcendental God who intervenes from time to time. This intervention is understood from the perspective that the world consists of three levels, namely heaven, earth and the underworld. Epistemologically seen, Young adhered to this theistic three-dimensional world-view. The book's main character 'sees' heaven, in a cognitive-realistic manner, as a place somewhere above, a place to which one can travel through space and time to be with God (Young 2007:214-215). Yet The shack's re-narration of God's nature fits snugly into a paradigm of what I would term a posttheistic and postsecular communion with God based on a postliberal engaging hermeneutics of the Christian Bible (Van Aarde 2008, 2009a, 2009b).

To me, Young, a non-professional public theologian, has found himself in the company of present-day influential theologians. For example, Elizondo (2002:47), in his essay 'On the streets of a fragile world', part of a collection of essays in the book Walking with God in a fragile world, published in the aftermath of September 11, said that Moltmann (one of the contributors to this collection of essays) would also

1.See 'The Shack Forum' at www. TheShackBook.com.

2.Mark Driscoll and Albert Mohler (in Challies 2008:2) see The Shack's conceptualisation of the Trinity as 'actually heretic' and 'undiluted heresy', respectively. Mohler is the president of the Southern Baptist Theological Seminary and Driscoll is the pastor of Mars Hill Church in Seattle. 
be a 'patripassionist'. New Testament scholar Bauckham (2001:xii), in his preface to the English version of The crucified God by Moltmann (1972), stated that Moltmann's emphasis on the passibility ${ }^{3}$ of God represents a departure from Orthodoxy's classical theism. According to this conceptualisation of God, God wanted Jesus to be crucified and God also abandoned Jesus while being crucified. However, the title of Moltmann's book, The crucified God, communicates a different conceptualisation. God's passibility ${ }^{4}$ - referred to ambiguously as love and as pain - means that God can be affected by people. God suffers with and for God's people. Their emancipation from evil, suffering and death brings God joy.

It should not be forgotten why, during the first few centuries of Christian theological history, theologians regarded the Holy Trinity not as a number of three but as a communion of three differences (Augustinus [1969]). In a recent book by Boff, one of the chapters is titled 'The divine family in the human family' (Boff 2009:119-127). As did Augustinus ([1969] 7.4-7), Boff (2009:119) also believed that the 'super-eminence of the Godhead surpasses the power of customary speech'. According to Augustinus ([1969] 5.9.10), 'human language labours altogether under great poverty of speech'. Boff put it as follows:

If one wants to achieve some understanding of the Holy Trinity one must take on this way of thinking and seeing the world. Suddenly, one discovers relations and realizes that everything is relation. The employed terminology itself already presupposes relations: there is no Father without Son, no Son without a Father. There is no Breath (this is the meaning of Holy Spirit) without someone breathing. The Holy Spirit is the Breath of the Father into the Son and the Breath of the Son into the Father... I emphasize that the three doesn't stand for the mathematical number within this context, it rather stands for the understanding that under the concept God there are differences that are not exclusive but inclusive, that are not opposing but in communion. The defining feature here is the union through relation, communion, and love.

(Boff 2009:120-121)

With regard to The shack and against its background of painful deprivation called 'the Great Sadness', this article aims to explain the dominant narrative point of view of The shack's plot. The pivotal perspective seems to be to narrate a process of transformation from bitter resentment to participating union with God. The transformation takes place within a relationship that the human has with each of the three personae. The dénouement of the plot flows into a participatory relationship that the protagonist has with the 'Three-in-one' and not with the three personae.

This article expresses appreciation for the plot and characterisation of both God and the people in the story as an illustration of 'public theology' (Van Aarde 2008:1213-1234). The value of this theology is critically assessed from a Pauline and Johannine perspective on God, the Christ and the Spirit.

Why Paul and John? There are indeed many other voices from the Christian Bible that can also serve as a lens and whose

3.'Passibility' is the technical term for the ability of God to suffer

4. The bodily suffering of Jesus on the cross indeed shows severe agony. By quoting Psalm 22:2 (Mk 15:33-39; Mt 27:45-47; Lk 23:44-48; Jn 19:28-30), the Gospe writers emphasise forsakenness and solitary grief. Jesus' suffering exemplifies martyrdom analogous to that of many other honourable sufferers in the history of God's people. Their visible pain would be understood by the agents of evil as dereliction. However, their suffering does not take away from the fact that martyrs commit their spirit 'into the hands of God' at the moment of dying, as echoed in Psalm 31:6 and as Luke 'remembered' what happened with Jesus (Lk 23:46) being crucified and Stephen being stoned (Ac 7:59). Therefore Van Tilborg (1988:906-907) correctly does not interpret Jesus's 'cry of dereliction' on the cross as an abandonment by God: '[T] he parallel texts [Qumran $1 \mathrm{QH} 5$; Jos As 12:11; 27:7-11] and parallel interpretations in the Septuagint [Wisd 2:18: 3 Macc 6:11] and the Targumim [Tg Ps 22:7, $12,21,221$ do not know a thing about a messianic or prophetic interpretation. 22.7 , $12,21,22]$ do not know a thing about a messianic or prophetic interpretation. Tim and again they use Psalm 22 to find words for the suffering of someone else, that is one who saw the Psalm - not exclusively but pre-eminently - as a verbalisation of real sufering. As a verbal enunciation the use of the Psalm points to the impotence of one's own words but also to the power of the words of Psalm 22: a last possibility of language to give expression in words to the absurdness of the suffering of someone persecuted.' perspectives on The shack's view on God, the Christ and the Spirit can be assessed. For example, Luke's narrative in Acts 2 presents another excellent point of view from which one can approach the issue at hand, although I believe that I can demonstrate the impact and influence of Pauline thinking on Peter's speeches in Acts (cf. Picheler 1999:741; Pervo 2006:51-147), including the speech at Pentecost (see Walker 2009:9-14). This speech is a remarkable emulation of 1 Thessalonians 1:6, the letter of Paul's that Donfried $(1990: 21,22)$ considered to be the closest to Luke's way of thinking, in which Paul writes about people who, in spite of much affliction, imitate Jesus by accepting God's gospel with joy, inspired by the Holy Spirit. The fabric of Peter's speech at Pentecost is interwoven with intertexts from the Septuagint that overlap and differ in important ways from Hebrew versions (see Steyn 1995:74-90). The almost cataclysmic, catastrophic nature of affliction is colourfully pictured in Peter's speech and so too the joy experienced in the hearts of all, irrespective of gender, and expressed by the lips of both old and young and of both masters and slaves, resulting in a journey described by another oxymoron, namely 'rest' and 'hope'. On this road, the traveller journeys as one who was dead and now is alive because she and he are liberated from the 'birth pangs of death'. (The LXX changes the 'chains of death' into the 'birth pangs of death', thus referring to the ultimate affliction that gives birth to authentic life [see Newman \& Nida 1972:49]).

In this regard, Luke coincides with both Paul and John. The focus on these two New Testament authors also confirms a truism from Rudolf Bultmann's pen. On 20 August this year, the New Testament community worldwide celebrated the birth of Bultmann 125 years ago. ${ }^{5} \mathrm{~A}$ few years after his retirement as New Testament professor at Marburg in June 1951, he wrote his magnum opus, Theologie des Neuen Testaments (Theology of the New Testament) (Bultmann [1948-1953] 1964). In this work, he stated that, in the New Testament, only 'two theologians' are outstanding: Paul and John (cf. Hamman 2009:399). For this reason, Bultmann ([1951] 1974:357-362) placed Paul and John in the Zentrum der neutestamentlichen Theologie (centre of New Testament theology) (cf. Boers 1979:10-12; Hahn 2006:139).

My article consists of two sections. The first section addresses the issue of reviewers of The shack often assessing its religious legitimacy and the value of its message by means of critically questioning its adherence to texts in the Christian Bible. According to The shack, such an evaluation would mean restricting God as if placing him in a box. The second section focuses on the accusation that, dogmatically seen, The shack's narrative point of view is heresy, especially because of its nonstandard view of Christian dogma with regard to God Triune. According to the God portrayed in The shack, such an evaluation would run along the lines of 'Honey, you have it all wrong'.

Another issue dealt with is traditional institutional religion versus an embracement of the present-day 'emerging church'. According to the Jesus portrayed in the The shack, he does not

create institutions; that's an occupation for those who want to play God. So no, I'm not too big on religion... and not very fond of politics or economics either. . . And why should I be? They are man-created trinity of terrors that ravages the earth and deceives those I care about. What mental turmoil and anxiety does any human face that is not related to one of those three?

(Young 2007:179)

In view of limited time and space, my own critical assessment of the notion of 'emerging Christianity' is not explicitly addressed in this article. ${ }^{6}$

Throughout the narration, various other important life matters criss-cross the three main issues in The shack, namely adherence

5.Rudolf Bultmann was the eldest child of pastor Arthur Kennedy Bultmann and his wife Helene Stern, born 125 years ago in 1884, in Wiefelstede, in the Großherzogtum Oldenburg (cf. Hamman 2009:1).

6.Nevertheless, see, inter alia, McKnight (2007) and Doorenbal (2008). 
to 'biblical correctness', to 'dogmatic correctness' and to 'ecclesiastical traditionalism'. One of the other issues is the theological problem of 'evil and humankind's free will'. Another is the 'power of forgiveness' against the background of 'hard' and 'soft' violence and the trauma of abuse within either the household of the biological family or the family of believers, for example in the case of both the author of The shack (William P. Young) and the protagonist of the story (the nominal Christian Mackenzie Philips). Such issues, certainly burning matters for many today, are closely linked to biblical exegesis. Therefore they create the expectation among the book's readers that answers will be discovered in the Bible. However, these are not addressed in this article.

Not only because The shack never quotes from the Bible but also because I believe so, the three issues of 'correctness' mentioned could, within the limited space of this article, enlighten the other questions as well. One of these is the question of whether The shack promotes 'universal salvation' for people, also those outside Christendom. The shack's protagonist asks Jesus, 'Is that what it means to be a Christian?' Jesus's response is

Who said anything about being a Christian ... Those who love me come from every system that exists. They were Buddhists or Mormons, Baptists or Muslims, Democrats, Republicans and many who don't vote or are part of any Saturday morning or religious institutions... I have no desire to make them Christians, but I do want to join them in their transformation into sons and daughters of my Papa, into my brothers and sisters, into my beloved.

(Young 2007:182)

As could be expected, such a remark would raise questions, not only from traditional Christian 'denominationalists' but also from nominal Christians who 'believe, but do not want to belong' (Avis 2003:108). Therefore, The shack's protagonist replies, 'Does that mean that all roads will lead to you?' As far as this deduction is concerned, The shack's Jesus does not admit to it being so but continues to say, '[W]hat it does mean to say is that I will travel any road to find you.' According to Gary Gilley (2008), an American pastor from Springfield, Illinois, The shack implies that people are on many roads that lead to their self-transformation: 'Jesus will join people where they are on that road and apparently aid in that transformation.' Assuming that Gilley's inference is correct, what should a professional theologian say? Is Gilley also correct when he says, 'This is certainly not the teaching of Scripture ...'?

This article does not retell the story of The shack through a paraphrased synopsis. Knowledge of the book's plot is assumed. This article does, however, provide a brief reflection. My assessment of the 'three correctnesses' endorses Young's main intent of his remarkable book. Both according to me and to Olson (2009:16-17), professor of theology at George W. Truett Theological Seminary of Baylor University in Waco, Texas, it is to learn to trust God.

In this article, three lengthy passages from The shack are quoted, these being words from God, the Son and the Spirit, respectively. The article concludes with a brief overview of Paul's and John's outlook on God, on Christ and on the Spirit and the readers of my article will be deliberately challenged to answer for themselves the question that Gilley (2008) pondered on: 'Does Young's theology agree with God's as revealed in Scripture?' The readers are asked to respond critically to Gilley's short answer: '[S] ometimes, but often Young totally misses the mark.' The article thus begins with the view that Scripture could be a box in which God is restricted. My own position is disclosed throughout the article but particularly so in my closing assessment of Paul and John as early Christian 'mystics'.

\section{GOD IN A BOX?}

The protagonist in the story is Mackenzie or Mack and he lives in the American Northwest. According to the author's foreword, he is the counterpart of the implicit reader (Young 2007:7-13).
Amid the volume of e-mails that The shack has generated since its publication, the following dialogue can be found on the internet:

"Mack is me, a guy who has made a mess of everything", Young says. "The book takes him outside everything familiar, back to the worst experience of his life and lets him recognize God is so much greater". Yet, as McVey, the minister from Tampa, says, "This pure grace of God has always divided people". Mohler, Driscoll and other evangelicals pick The Shack apart plank by plank. No, God can't be presented as a woman. No, the three parts of the trinity did not become fully human. Yes, there is a hierarchy in the Holy trinity with God the Father in command. Yes, God will punish sin. Young shrugs them off. Out there in America, where only three in 10 people attend weekly worship services and millions are ignorant of the Bible, his readers struggle to find a good God amid their pain. As for critics, he shakes his head. "I don't want to enter the Ultimate Fighting ring and duke it out in a cage-match with dogmatists, I have no need to knock churches down or pull people out," he says. "I have a lot of freedom by knowing that you really experience God in relationships, wherever you are. It's fluid and dynamic, not cemented into an institution with a concrete foundation. But it's not about me. I have everything that matters, a free and open life full of love and empty of all secrets."

(Wolfe 2008)

The narrative time begins when Mack is nearing 56, a slightly overweight, hard-working white man and father of five of which the darling last-born, Missy, has just turned 13. Mack's own story, however, starts when he too was 13 . This was when he, in the context of a typical reveille, gave his soul to Jesus with the confession of conversion that his father, a pastor, was an alcoholic and a wife beater. When his father learnt about this confession, he tied Mack to a tree in the backyard of the manse and beat him with a belt, all the while Bible texts flowing from his mouth, the very same mouth that was taking gulps from the bottle in between. The narrative time's plot really starts only when Mack's actual 'Great Sadness' began. He and three of his five children went on a camping trip without his wife, Nan, to a panoramic valley in the Columbia River Gorge's Multnomah Falls and Wallowa Lake near the town of Joseph in Oregon. Two of his children were playing in a canoe on the river and, when it flipped, Mack managed to save them. During this commotion, however, Missy, who had been left alone at the camp-site, was abducted and murdered by a serial killer known as the 'Little Ladykiller'. Her body was not found, only her bloodstains in an abandoned and dilapidated shack deep in the forest. Mack sank into a profound depression, which the narrator describes as the 'Great Sadness'. The plotted story begins three years later when Mack receives an enigmatic note in his mailbox from 'Papa' asking him to meet at the shack; Nan always used to refer to God as 'Papa'. Mack, despite having undertaken some theological studies at a seminary, was only a nominal Christian.

At the end of Mack's journey of encounters with Papa, Jesus and Sarayu (Sanskrit for 'air and wind'), God shows Mack, in an altered state of consciousness, where Missy's body is, although, in real life, it is a friendly policeman who, after Mack's spiritual journey, shows Mack and Nan the place. Therefore, is the story's genre not pure fiction rather than an historical novel? Or is it perhaps a story similar to those we find in the narrative gospel: transcendence transparent within the reality of people?

I have already pointed out that no Bible texts are quoted in the story, neither by Mack nor by any of the other characters, be they worldly characters or divine characters.

Without reference to specific biblical texts, The shack still demonstrates an exceptional use of the Bible. The author does not let professional theologians' exegetical practices prescribe to him. His 'use of the Bible' is what Bruegemann (2005:170-171) described as the 'new characteristics of postliberal exegesis'. Part of this is what Tillich ([1996] 2007:46, 47) called the irrelevance and relevance of the Christian message. He put it as follows: 
Now this means that Christianity is not based on an idea or a set of symbols. They are there. They are used. But the church is based on something that has happened in time and space - the appearance of a man who is called Jesus, who was received by the disciples as the expected Christ... This event was received in the church traditions, which were combined in the process leading, four hundred years later, to the biblical canon. Afterwards they went on developing from century to century. As this happened the churches not only preserved and explained the event. They also concealed and distorted it. Again and again they made it ununderstandable, unreceivable and irrelevant.

(Tillich [1996] 2007:46, 47)

Christians do not have to subject themselves blindly and without any criticism to biblical or dogmatic propositions, particularly when such 'truths' harm a person's 'inner' being. Tillich ([1996] 2007) preferred the approach by Schleiermacher ([1830] 1928), which he termed a 'responding-listening and meditative' use of the Bible. To use the terms of Bruegemann (2005:170-171), we find in The shack a creative 'act of imagination' that is more susceptible to a 'critique of ideology'. This takes into account that 'every reader and every reading is to some extent contextual', in other words exegetes approach the Bible with their total humanity, including their presumptions, historical memories, current experiences and full physical beings as mortals, which, in Paul's and John's terms, is as human as sarkikos. As far as Brueggemann is concerned, this form of Bible usage has a 'practical urgency to $i t^{\prime}$, for institutional Christian religion has for too long harmed people by, inter alia, using the Bible and the dogma of classic theism as a weapon. The 'pastor-teacher' Gilley (2008), in his critical review of The shack, was quite correct in his observation that The shack, like many other books today, decries theology on the one hand, while offering its own brand on the other.

Just like the 'romanticist' Friedrich Schleiermacher ([1830] 1928), Young chose to present his interpretation of the 'Jesus cause' (Sache Jesu) in story form. According to Gilley (2008), a story has 'the advantage of putting forth doctrine in a livelier manner than a systematic work can do - which is why we find most of Scripture in a narrative form'. But then Gilley expected answers from Young to questions which, in my view, arose from his own ideological prejudice: 'The question is, does Young's theology agree with God's as revealed in Scripture? The short answer is "sometimes" but often Young totally misses the mark.'

My approach is different. According to Bruegemann (2005), a post-liberal and post-theistic exegesis creates a consciousness that in theology 'life-and-death matters are at stake both for the interpreter and for the community of interpretation'.

For this reason, seen from a specific angle, I appreciate the fact that the protagonist in The shack distances himself from the hermeneutics and biblical views that he was taught at the theological seminary:

In seminary he [Mack] had been taught that God had completely stopped any overt communication with moderns, preferring to have them only listen to and follow sacred Scripture properly interpreted, of course. God's voice had been reduced to paper, and even that paper had to be moderated and deciphered by the proper authorities and intellects... Nobody wants God in a box, just in a book.

(Young 2007:65-66)

The approach as to what constitutes God's Word is presented in The shack by the fact that God communicates to people through their thoughts, rather than through what is written on paper (Young 2007:195)

The author of The shack says that the protagonist of the story is aware of the fact that also his view of the Bible is subjective. He, however, relativises his subjectivity by regarding subjectivity as relationality. Thus viewed, relationality ensures that we 'begin to better recognize [the Holy Spirit's] voice as we continue to grow our relationship' (Young 2007:196). However, this persuasion does not diminish the belief that '[i]n a special way, in Christian spirituality, the Christian scriptures are recognized as the normative text that guides Christian living and belief' (Perrin 2007:215). My meditative listening and reading of Scripture certainly do not pertain to a pre-critical use of biblical texts either. In his book Studying Christian spirituality, David Perrin puts it as follows:

Classic texts [such as the Christian scriptures], by their very nature, are identified as reflecting and breaking open the experience of the reading community in different historical and cultural settings. The many ways of living the mystery of God are authenticated by the great many approaches to reading and interpreting the various texts that have come down through the ages in the Christian traditions. The hermeneutical perspective allows texts from previously marginalized groups within the Christian traditions to bring their voices forward, and to be tested, in conversation with those already recognized as valuable and normative voices.

(Perrin 2007:214)

One of these 'normative voices' is that of Athanasius of Alexandria. The Athanasian Trinitarian doctrine (Moreschini \& Norelli 2005b:44-46) is the product of orthodox classic theism. From a postivistic perspective, modernist exegetes maintain orthodoxy through their view that the Bible's authority is based on an objective view of what truth is. Such a perspective on Scripture excludes a hermeneutical approach that is embedded in a relational view of what truth is. I am an advocate of what I term 'engaged hermeneutics', which, in turn, is a product of posttheism and not of classical theism.

Posttheism acknowledges that no world-view is final and that the biblical manner of speaking is therefore not final either. Within the Christian faith community, engaged hermeneutics - through a meeting with Jesus or with the 'word' that Jesus proclaimed or with the 'word' that proclaims Jesus's message - aims to establish the important insight that faith does not uphold propositions as truth but presumes a living existential relationship with God. Even though Christians are still part of history in this saeculum, they already become new human beings the very moment that they make an affirmative decision about faith. Engaged hermeneutics pertains to the interpretation of Scriptures in such a way that it can be understood as addressing kerygma. Such an interpretation is not devoid of scientific means, although a scientific engagement is not without presuppositions because it questions critically and with suspicion the intention and reception of Scriptures (Van Aarde 2009a). The biblical and theological hermeneutics found in The shack illustrates such a hermeneutics of suspicion, as can be seen in the following quotes.

\section{THE GODHEAD - 'HONEY, YOU HAVE IT ALL WRONG'}

\section{Papa (Young 2007:100-102)}

Mack felt the onset of information overload.

"There's that whole Trinity thing, which is where I kind of get lost". Papa laughed a long rich belly laugh that made Mack want to join in.

"To begin with, that you can't grasp the wonder of my nature is rather a good thing. Who wants to worship a God who can be fully comprehended, eh? Not much mystery in that."

"But what difference does it make that there are three of you, and you are all one God. Did I say that right?"

"Right enough." She grinned. "Mackenzie, it makes all the difference in the world!" She seemed to be enjoying this. "We are not three gods, and we are not talking about one god with three attitudes, like a man who is a husband, father, and worker. I am one God and I am three persons, and each of the three is fully and entirely the one."

The "huh"? Mack had been suppressing finally surfaced in all its glory.

"Never mind that", she continued. "What's important is this: If I were simply One God and only One Person, then you would find 
yourself in this Creation without something wonderful, without something essential even. And I would be utterly other than I am."

"And we would be without. . .?" Mack didn't even know how to finish the question.

"Love and relationship. All love and relationship is possible for you only because it already exists within Me, within God myself. Love is not the limitation; love is the flying. I am love."

"You do understand," she continued, "that unless I had an object to love - or, more accurately, a someone to love - if I did not have such a relationship within myself, then I would not be capable of love at all? You would have a god who could not love. Or maybe worse, you would have a god who, when he chose, could only love as a limitation of his nature. That kind of god could possibly act without love, and that would be a disaster. And that, is surely not me."

With that, Papa stood up, went to the oven door, pulled out the freshly baked pie, set it on the counter and, turning around as if to present herself, said, "The God who is - the I am who I am - cannot act apart from love!"

\section{The wind (Young 2007:209, 210) Sarayu}

When Mack opened his eyes he had to immediately shield them from a blinding light that overwhelmed him. Then he heard something. "You will find it very difficult to look at met directly," spoke the voice of Sarayu, "or at Papa. But as your mind becomes accustomed to the changes, it will be easier."

He was standing right where he had closed his eyes, but the shack was gone. .

He turned back to Sarayu, who still stood next to him. Although she was still difficult to look at directly, he could now make out symmetry and colors embedded within patterns, as if miniature diamonds, rubies, and sapphires of all colors had been sewn into a garment of light, which moved first in waves and then scattered as particulate.

"It is all so incredibly beautiful," he whispered, surrounded as he was by such a holy and majestic sight.

"Truly," came the voice of Sarayu from out of the light. "Now, Mackenzie, look around."

\section{Relationships (Young 2007:213)}

"We are not only able to see the uniqueness of one another in color and light, but we are able to respond through the same medium. But this response is very difficult to control, and it is usually not intended to be restrained as this one is attempting. It is most natural to let its expression just be."

"I don't understand," Mack hesitated. "Are you saying that we can respond to one another in colors?"

"Yes," Sarayu nodded, or at least that's what Mack thought she did. "Each relationship between two persons is absolutely unique. That is why you cannot love two people the same. It simply is not possible. You love each person differently because of who they are and the uniqueness that they draw out of you. And the more you know another, the richer the colors of that relationship."

\section{The Carpenter (Young 2007:141-143)}

Jesus: . . "But now tell me, where do you spend most of your time in your mind, in your imagination, in the present, in the past, or in the future?"

Mack thought for a moment before answering: "I suppose I would have to say that I spend very little time in the present. For me, I spend a big piece in the past, but most of the rest of the time, I am trying to figure out the future."

"Not unlike most people. When I dwell with you, I do so in the present - I live in the present. Not in the past, although much can be remembered and learned by looking back, but only for a visit, not an extended stay. And for sure, I do not dwell in the future you visualize or imagine. Mack, do you realize that your imagination of the future, which is almost always dictated by fear of some kind, rarely, if ever, pictures me there with you?"
Again Mack stopped and thought. It was true. He spent a lot of time fretting and worrying about the future, and in his imaginations it was usually pretty gloomy and depressing, if not outright horrible. And Jesus was also correct in saying that in Mack's imaginations of the future, God was always absent.

"Why do I do that?" asked Mack.

"It is your desperate attempt to get some control over something you can't. It is impossible for you to take power over the future because it isn't even real, nor will it ever be real. You try and play God, imagining the evil that you fear becoming reality, and then you try and make plans and contingencies to avoid what you fear."

"Yeah, that's basically what Sarayu was saying,' responded Mack. "So why do I have so much fear in my life?"

"Because you don't believe. You don't know that we love you. The person who lives by their fears will not find freedom in my love. I am not talking about rational fears regarding legitimate dangers, but imagined fears, and especially the projection of those into the future. To the degree that those fears have a place in your life, you neither believe I am good nor know deep in your heart that I love you. You sing about it; you talk about it, but you don't know it." Mack looked down once more at the water and breathed a huge sigh of the soul. "I have so far to go."

"Only about a foot, it looks to me," laughed Jesus, placing his hand on Mack's shoulder. It was all he needed and Mack stepped off the dock. In order to try and see the water as solid, and not be deterred by its motion, he looked up at the far shore and held the lunch bags high just in case.

The landing was softer than he had thought it would be. His shoes were instantly wet, but the water did not come up even to his ankles. The lake was still moving all around him and he almost lost his balance because of it. It was strange. Looking down it seemed that his feet were on something solid but invisible. He turned to find Jesus standing next to him, holding his own shoes and socks in one hand and smiling.

"We always take off our shoes and socks before we do this," he laughed.

Mack shook his head laughing as he sat back on the edge of the dock. "I think I will anyway." He took them off. Wrung out his socks, and then rolled up his pant legs, just to be sure.

They started off with footwear and lunch bags in hand and walked toward the opposite shore; about a half mile distant. The water felt cool and refreshing and sent chills up his spine. Walking on the water with Jesus seemed like the most natural way to cross a lake, and Mack was grinning ear to ear just thinking about what he was doing. He would occasionally look down to see if he could see any lake trout.

"This is utterly ridiculous and impossible, you know," he finally exclaimed.

"Of course," assented Jesus, grinning back at him.

They rapidly reached the far shore and Mack could hear the sound of rushing water growing louder, but he couldn't see its source. Twenty yards from the shore he stopped. To their left and behind a high rock ridge he could see it, a beautiful waterfall spilling over a cliff's edge and dropping at least a hundred feet into a pool at the canyon floor. There it became a large creek that probably joined the lake beyond where Mack could see. Between them and the waterfall was an expanse of mountain meadow, filled with booming, wildflowers haphazardly strewn and seeded by the wind. It was all stunning, and Mack stood for a moment breathing it in. An image of Missy flashed in his mind, but didn't settle.

\section{'God is a verb not a noun'}

The shack's God figure becomes fully human (Young 2007:99) and not only abandons any notion of authority or power but even submits to human beings as well and, by the end of the book, is reduced to being a servant of people (Young 2007:145), the reason being 'Because we want you to join us in our circle of relationship. I don't want slaves to my will; I want brothers and sisters who will share life with me.' And humankind's response: 'And that's how you want us to love each other, I suppose? I mean between husbands and wives, parents and children. I guess in any relationship?' 
In this sense, Young (2007:194, 204) declared God to be a verb and not a noun. God does not 'do humiliation, or guilt, or condemnation' (Young 2007:223). Earlier on, God said, 'I don't need to punish people for $\sin$, sin is its own punishment, devouring you from the inside. It is not my purpose to punish it; it's my job to cure it' (Young 2007:120). The shack's God likes to cook and each member of the Trinity prepares some part of the meal (Young 2007:105). After the meal, God announces a time of devotion, which turns out to be Jesus saying, 'Papa, I loved watching you today ...' (Young 2007:107).

The Spirit shares these dynamics: 'She is Creativity; she is Action; she is Breathing of Life' (Young 2007:110). The shack's Jesus, 'as a human being, had no power within himself to heal anyone' (Young 2007:100). He healed by trusting in the Holy Spirit. Jesus, the Spirit says, 'is just the first to do it to the uttermost - the first to absolutely trust my life within him ...' The shack's protagonist responds to Jesus that he cannot be part of the church and Jesus replies, 'It is simple Mack, it's all about relationships and simply sharing life' (Young 2007:178). Earlier on, Jesus told Mack how to get out of his mess: '[B]y re-turning. By returning back to me. By giving up your ways of power and manipulation and just come back to me' (Young 2007:147).

\section{AN AFTERWORD FROM PAUL AND JOHN: BELIEVING IS TRUSTING AND IT IS ALL ABOUT RELATIONSHIPS}

Young, in an interview with the New York Times (Rich 2008), said that the shack is a metaphor for 'the house you build out of your own pain'. In a telephonic radio talk hosted by the journalist Drew Marshall ${ }^{7}$, Young also stated that the shack is a metaphor 'for the places you get stuck, you get hurt, you get damaged ... the thing where shame or hurt is centered'.

In my opinion, it is in their God talk that a great deal of commonality between Young and the apostle Paul exists, taking into account that neither Young nor Paul withdrew from a typical three-dimensional world-view of heaven above earth and Hades under the surface of the earth. Nevertheless, their God talk expresses more of a present immanent communion with the transcendental God than an expectancy of authenticity that still lies in the future and exists outside humankind's immanent time and space. It is as if Paul and John - and for that matter, Young too - draw the end time into the sphere of the here and now by passionately talking about communion with God as a process of the future, inhaled by the present. This process of communion as transcendence in everydayness is comparable to the picture of the father in Luke's parabolic speech of Jesus about the lost and traumatised sibling: the father saw from afar, ran towards the child and, together, they engaged each other at a celebration of homecoming. So, Paul is jubilant:

So we do not lose heart. Though our outer nature is wasting away, our inner nature is being renewed every day. For this slight momentary affliction is preparing for us an eternal weight of glory beyond all compassion. . . For we know that if the earthly tent we live in is destroyed, we have a building from God, a house not made with hands, eternal in the heavens. Here indeed we groan, and long to put on our heavenly dwelling. .. For while we are still in this tent, we sigh with anxiety... He who has prepared us for this very thing is God who has given us the Spirit as a guarantee. So we are always of good courage... So whether we are at home or away, we make it our aim to please him.

(2 Cor 4:16-5:10; English translation: Revised Standard Version, 2nd edn.)

In 2 Corinthians 3 and 4 , Paul talks about the two dispensations that human beings find themselves in. These he describes as an old covenant and a new covenant. The first is symbolised by the name Moses and the second by Christ, the kyrios. The first takes on the form of 'stone tablets' (3:3), in other words it has to do with scripture or the letter. The second is not of stone but is human in nature. In the former, what is written is written in ink, while, in the latter, the 'spirit of the living' God writes on fragile hearts (en plaxin kardiais sarkinais).

This spiritual existence is described as an existence 'in Christ' (3:15). According to Paul (3:17), the pneuma (Spirit) is the kyrios (Lord). People who confess that the pneuma (Spirit) is the kyrios (Lord) and that the Lord is the Spirit are free. This freedom has many manifestations and forms. Here, in the second Corinthian letter, freedom means to be free from the ties that a written legalistic code imposes on people. The 'letter' - in other words the stone tablets - does not liberate people but, instead, kills them (to gramma apoktenei - 3:6). People who are free are people who undergo a metamorphosis by increasingly taking on the glory of the Lord, the kyrios (doxa kuriou - 3:18).

In view of Paul's other letters, this 'glorification' can be interpreted as the process by which mortals who, free from the shackles of death, can now share in that which is, in reality, indescribable, namely becoming a part of God, being in communion with God as if it is an experience of astonishing, illuminating light, 'die himmliche Lichtglorie' (Windisch [1924] 1970:129), participation in a glory (doxa) that overwhelmingly exceeds the limitations of the mortality of being human. This glorification takes place in a mysterious way and is the doing of the kyrios (Lord), which is the pneuma (Spirit) (kathaper apo kuriou pmeumatos - 3:18). Glorification pertains to an altered state of consciousness: 'Whereas Moses' glory was visible on his face, the Spirit-worked glory is not visible on the outside' (Van Kooten 2008:325). Malina and Pilch formulated it as follows:

The word 'glory' that appears frequently in the whole passage refers to the external, outward features or characteristics of some entity that reveal the true, lofty status or value of a person or thing. Marvellous external traits and lofty internal qualities go together, the visible being indicative of the invisible.

(Malina \& Pilch 2006:140)

According to Dunn, it

was having this ministry that kept Paul going ... Paul sees his commission as precisely the proclamation of this Christ in order that "the light of the knowledge of the glory of God in the face of Christ" might shine to dispel the darkness from the hearts of many others as it had already for Paul and his converts (4:5-6).

(Dunn 2009:848)

Lambrecht put it this way:

The passage [2 Cor. 3:7-18] is allusively autobiographical. However, what is said about the splendor and freedom of the new covenant, as well as about the transformation from glory to glory, applies to Christians of all times and places.

(Lambrecht 1999:62)

What Paul conveys in the second letter to the Corinthians is that he experiences this metamorphosis as a painful process. It is a process that can be described as the simultaneous destruction of the human's mortal body (4:11) and the renewal thereof during a person's life, as happened to Jesus's body (4:10). The process of glorification, both through destruction and renewal, has a redemptive result. The result lies in communion with God. Renewal comes in the form of the resurrection from death and is not possible without the body being destroyed, which, in the case of Jesus, was crucifixion. Therefore Jesus is both the archetype ('Urbild') and the type ('Vorbild').

The debate of whether or not critical theology has simply reduced Jesus to an exemplary human being without a Divine being was given impetus in the 18th century with the 'systematic theology' of Schleiermacher ([1830] 1928). This took the form of a narrative 'novel', particularly with reference to the interpretation by Schleiermacher ([1805] 1843) of the Pauline and Johannine 'incarnation' theology. This took the form of a story of a family 
and friends getting together for a meal on Christmas Eve (cf. inter alia Hertel 1965:205). ${ }^{8}$ Clements referred to it as follows:

Protestant liberalism has often been charged with reducing the historical Jesus to a moral and spiritual example or hero, in contrast to the one who saves lost [hu]mankind by his sacrifice. Schleiermacher's Christ, however, does not just serve as a spur to moral endeavour. His opening christological thesis runs: "If the spontaneity of the new corporate life is original in the Redeemer and proceeds from him alone, then as an historical individual he must have been at the same time ideal (i.e. the ideal must have been completely historical in him), and each historical moment of his experience must at the same time have been borne within the ideal" [Schleiermacher [[1830]] 1928:377]. The new life is not generated by the believer, or by the community itself, but is actually imparted through communion with the Jesus in whom it has its source and who is its "ideal realization". It must be noted, however, that when Schleiermacher speaks of "ideality" (Urbildlichkeit) he does not mean an abstract model of perfection, but something nearer the Platonic "form", that which actually imparts reality to a particular object which participates in it. Also, while Schleiermacher speaks of the "exemplary" status of Jesus (Vorbildlichkeit) he does not mean a kind of model to be copied, but rather the way in which Jesus himself exemplified the human race by solidarity with it in the fullness of humanity [my emphasis].

(Clements 1987:54-55)

Paul's intention is in line with this. As Jesus's deprivation offers the possibility of life to others, so Paul's process of 'dying' creates the opportunity for the Corinthians to live (4:12). It is by thus understanding Paul that Albert Schweitzer (1930:1) described Paul as a mystic. Schweitzer described mysticism as the 'state' of being human in which the tension between the earthly (immanence) and the super mundane is transcended. This transcendence occurs while a person is still part of the earthly and finite dispensation. The person who has overcome has not necessarily died. This occurs while a person is still alive in her or his mortal state while she or he is, at the same time, in some mysterious way, already part of the immanent and the eternal (Schweitzer 1930:4). In 2 Corinthians 5:17, Paul describes such transcendence amid the daily existence as somebody who is 'in Christ'. Such a person is a new being: '[T] he old has passed away; behold, the new has come.'

In John's Gospel, too, the 'way' with Jesus is described as 'life'. In chapters 14 to 17, Jesus refers to himself as the way, the truth and the life (14:6). Evil is the ruler or prince of this world but has no hold on Jesus (14:30). Jesus's followers find themselves in a situation likened to branches attached to a vine, in other words they are attached to Jesus's way (chapter 15). It is a way that presupposes rejection and death (15:18-27). If Jesus's followers do as Jesus does, they will do what God wants them to do. That which they have to do is revealed to them by the 'spirit of the truth' (to pneuma tes aletheias) (14:17). What they have to do is to love, even if they are rejected as Jesus was (14:21). Jesus is the face of God (14:9) and Jesus does what God does. This 'doing' is the way upon which Jesus and his followers find themselves. The truth is that they cannot see God but they can see Jesus and the deprivation that Jesus and they are subjected to. The 'spirit of truth' is that, despite the reality of deprivation, this way is authentic existence.

Living like this means that, while on this way, evil has no hold on them. It is, on the contrary, 'the spirit of the truth', which, together with Jesus and God, comes to life with a person in the same room (monen par' auto poiesometha - 14:23), the paraclete, who is humankind's 'partner' (par' humin menei) and is in them

8. 'Die in den Monologen entwickelte Anschauung, dass es Freiheit und Unendlichkeit nur in der Ubernahme des menschlichen Daseins in seiner Endlichkeit und Zeitlichkeit geben kann, wird in der Weihnachtsfeier in seiner theologischen Vorausstzung deutlich. Aus der Angewiesenheit des Menschen auf Erlösung und Voraussetzung deullich. Aus der Angewiesenhelt des Menschen auf Erlosung und Heil heraus legt Schleiermacher seine christologische Konzeption dar, die - aus den Grenzen theologischer Begrifsbildung befreit - besagt, dass in Christus der Mensch an sich oder das Urbild des wahren Menschen geschichtliches Ereignis geworden ist' (Hertel 1965:205) (en humin estai - 14:17). This results in peace, love, joy and the overcoming of fear (14:27-28). Communion with God is to live with God in the 'same room' or, in Young's re-narration, communion in a shack. According to Bultmann, the 'question ... which activates the section vv. 15-24 is this:

What is this love, which is directed to Jesus? And this question, too, has to be understood in the context of the 'farewell situation.' Can the disciples still love him, when he has gone? Can the next generation love him, without having a personal relationship to him? Can it, for instance, take him to itself with the love of the mystic? The clear presupposition of vo. 15, 21,23f. is that the believer must love Jesus, indeed that he wants to do so, and this presupposition implies that love is a personal relationship... Over against this, a new understanding of love is unfolded: the agapan [to love] . . can only be a terein [keeping] of his entolai [demands], of his logos [word] ... [S]o here the old Jewish-Christian eschatology is re-interpreted. What is hoped for, and what is promised is not one day to become a direct actuality, but it will in fact be present as the believing existence is carried through.

(Bultmann [1964] [1966] 1971:613)

\section{RISUS PASCHALIS, WHICH MEANS 'THE EASTER LAUGHTER'}

The question now is: What does Paul's and John's 'mysticism' have to do with the book The shack?

At the beginning of the article, I referred to Tertullian, the theologian who coined Trinitarian vocabulary. Both in The shack and in Paul's and John's (similarly, also Luke's) mysticism communion between God and human beings - leads to joyful exultation. Joy embedded in a spiritual well-being can be the 'religious grammar' by means of which one can cope with 'Great Sadness' and still communicate and live love. However, it comes as no surprise to learn that someone like Tertullian ([1961]) condemned laughter, jesting and play as well as 'feminine ambition and luxury' (Moreschini and Norelli 2005:342), with the result that, according to Mikhail Bakhtin (1984), in medieval times, play and humour were relegated to unofficial feasts. If the church argued that faith's 'grammar' can be articulated only in 'monolithic seriousness', the faith community would, according to Bakhtin, oppress, frighten, bound, lie and wear 'the mask of hypocrisy' (Bakhtin 1984:94).

Jacques Derrida (1978:278-293) criticised theology's tendency to formalise belief experiences. Generally seen, this is what happened in pre and post-Reformational scholasticism in its association with Western metaphysics. Derrida (1978:292) called it 'ontotheology' and said that it was 'turned towards the lost or impossible presence of the absent origin' and therefore was 'saddened, negative, nostalgic, and guilty.'

Fortunately, 'Googling' while busy with theological research can produce happy results as well. Searching the citation impact of Moltmann ([1971] 1973) on 'theology and joy', an Easter sermon by Dr. John M. McCoy (2000) appeared on the computer screen. The sermon begins as follows:

Long ago in southern Germany, in Bavaria, during the late middle ages there was a custom in many of the Catholic churches of that region that was quite unusual. At the end of the Easter church service, the Easter Mass, the priest would leave the altar and come down among the people and lead the congregation in what was called the 'Risus Paschalis' which means 'the Easter laughter.' The priest would tell funny stories and sing comical songs, and the church would ring with laughter. Of course the point was obvious, the laughter echoing through the church was a tangible testimony to the merriment born out of the tidings of this great day, Jesus Christ alive and loose among us. All the forces that conspired to lay him in his tomb, the fury, the lovelessness, the violence, the vaunted powers of kings and empires, they are made a laughing stock.

Do you get it? It's a thing to ponder. The laughter of God, the laughter of his people rolling out into the spring time world from 
doors and windows of churches where the story is told on an Easter day.

Laughter is a wonderful gift of God, and those ancient mediaeval Catholics in Bavaria were right to give a space for mirth and laughter in the Easter worship of the church. But on this greatest day of the church year I want to be sure that none of us miss that utterly unique thing that is the Risus Paschalis, the Easter laughter.

Certainly the most obvious element of this laughter is joy. But I think there is a great deal more than just joy. You see the laughter of this day is the laughter that bursts forth when the totally unexpected, the completely unanticipated, the utter surprise of a thing strikes us.

(McCoy 2000:n.p.)

Seen through the lens of this gifted minister's sermon, I suddenly realised why Young's public theology rings true with my postliberal hermeneutics, why the absence of biblical verses in The shack being quoted does not bother me and how it is possible to imagine that Tertullian's Against Praxeas could very well be renamed Against the shack.

Not counteracting grief in a conscious way with play is to displace the worth of authentic spirituality. As Jürgen Moltmann ${ }^{9}$ put it in his Theology and joy:

Only those who are capable of joy can feel pain at their own and other people's suffering. A man who can laugh can also weep. A man who has hope is able to endure the world and to mourn .. . So Easter freedom does not permit us to escape from the world or to forget about it. Rather it leads us critically to accept the world situation with its unacceptable moments and patiently to bring about change in the world so that it may become a place of freedom for humankind. Thus both the laughter of Easter and the sorrow of the cross are alive in liberated [human beings]. They are not only laughing with those who laugh and weeping with those who weep, as Paul proposes in Romans 12:15, but they are also laughing with the weeping and weeping with the laughing as the Beatitudes of Jesus recommended. Their game always points critically at the oppressors. It therefore constantly provokes harassment by those who prohibit laughter because they fear liberty.

(Moltmann [1971] 1973:52, 53)

However, as an exegete, theologian and humanist, I also realise now why The shack helps me to read Paul and John in light of remarks that I have recently made with regard to postsecular spirituality (Van Aarde 2009b):

What needs to be avoided is the capturing of the faith experiences of biblical characters in a fixed-for-always proposition-like format. Such a religious set-up would be catastrophic to living faith. What is needed is the encountering of the various dazzling spiritual experiences, witnessed in the Bible. This needs to be done in such a way that through our process of retelling and reliving them, they would display a form which conveys a message of hope congenial, on the one hand, to both the ancient biblical evidence and past religious and confessional traditions and, on the other hand, to our own personal present-day spirituality. Such an encounter speaks of living faith when it is proclaimed, confessed, sung and prayed for the very first time.

\section{REFERENCES}

Augustinus, [1969], De Trinitate, eds. W.J. Mountain \& F. Glorie, Brepols, Turnhout (CCL 50).

Avis, P., 2003, A church drawing near: Spirituality and mission in a post-Christian culture, T \& T Clark, London.

Bakhtin, M., 1984, Rabelais and his world, transl. H. Iswolsky, Indiana University Press, Bloomington.

Bauckham, R., [1972] 2001, 'Preface', in J. Moltmann, The crucified God, pp. ix-xvi, SCM, London (SCM Classics).

Bethune-Baker, F., 1903, 'Tertullian's use of substantia, natura, and persona', Journal of Theological Studies 4, 440-442.
Boers, H., 1979, What is New Testament theology? The rise of criticism and the problem of a theology of the New Testament, Fortress Press, Philadelphia.

Boff, L., 2009, Saint Joseph: The father of Jesus in a fatherless society, transl. A. Guilherme, Wipf Stock Publishers (Cascade Books), Eugene.

Bruegemann, W., 2005, 'The re-emergence of Scripture: Postliberalism', in P. Ballard \& S.R. Holmes (eds.), The Bible in pastoral practice: Readings in the place and function of Scripture in the church, pp. 153-173, Eerdmans, Grand Rapids.

Bultmann, R., [1948-1953] 1964, Theologie des Neuen Testaments, 4 Auflage, Mohr Siebeck, Tübingen.

Bultmann, R. [1951] 1974. Theology of the New Testament, vol. 1, transl. K. Grobel. SCM Press, London.

Bultmann, R., [1964] [1966] 1971, The Gospel of John: A commentary, transl. G.R. Beasley-Murray, from the 1964 German printing, with the Supplement of 1966, Basil Blackwell, Oxford.

Challies, T. 2008. The Shack: Unauthorized theological critique. Nimble Books, Ann Arbor.

Clements, K.W., 1987, Friedrich Schleiermacher: Pioneer of modern theology, Collins, London.

Derrida, J., 1978, 'Structure, sign and play in the discourse of the human sciences', in Writing $\mathcal{E}$ difference, transl. A. Bass, pp. 278-293, Routledge, London

Donfried, K.P., 1990, '1 Thessalonians, Acts and the early Paul', in R.F. Collins (ed.), The Thessalonian correspondence, 3-26, Leuven University Press, Leuven (Bibliotheca Ephemeridum Theologicarum Lovaniensium LXXXVII).

Doorenbal, R., 2008, 'Een complex en fascinerend fenomeen: Een karakterisering van de Emerging Church Beweging', Theologisch Debat 5(3), 18-24.

Dunn, J.D.G., 2009, Christianity in the making, Volume 2: Beginning from Jerusalem, Eerdmans, Grand Rapids.

Elizondo, V., 2002, 'On the streets of a fragile world', in J.R Langford \& L.S. Rouner (eds.), Walking with God in a fragile world, pp. 47-58, Rouman \& Littlefield Publishers, Lanham.

Evans, E., 1948, Tertullian's treatise against Praxeas, SPCK, London.

Gilley, G.E., 2008, Book review: The shack, viewed 10 January 2008 from http://www.svchapel.org/resources/BookReviews/ bookreviews.asp?ID=387.

Hahn, F., 2006, Studien zum Neuen Testament, Band 1, Mohr Siebeck, Tübingen (WUNT 191).

Hamman, K., 2009, Rudolf Bultmann: Eine Biographie, Mohr Siebeck, Tübingen.

Hertel, F., 1965, Das theologische Denken Schleiermachers, Zwingli Verlag, Zürich.

Lambrecht, J., 1999, Second Corinthians, The Liturgical Press, Collegeville (Sacra Pagina Series 8).

Malina, B.J. \& Pilch, J.J., 2006, Social-science commentary on the letters of Paul, Fortress Press, Minneapolis.

McCoy, J.M., 2000, Risus paschalis, viewed 10 January 2008, from www.newcelebrations.com/risus_paschalis_sermons.htm.

McKnight, S., 2007, 'Five streams of the emerging church: Key elements of the most controversial and misunderstood movement in the church today', Christianity Today posted 19 January 2007, 08:46.

Moltmann, J., [1971] 1973, Theology and joy, transl. R. Ulrich, SCM, London.

Moreschini, C. \& Norelli, E., 2005a, Early Christian Greek and Latin literature: A literary history, Volume one: From Paul to the age of Constantine, transl. M.J. O'Connell, Hendrickson, Peabody.

Moreschini, C. \& Norelli, E., 2005b, Early Christian Greek and Latin literature: A literary history, Volume two: From the Council of Nicea to the beginning of the Medieval period, transl. M.J. O'Connell, Hendrickson, Peabody.

Motoko, R., Christian novel is surprise best seller, viewed 24 June 2008, from www.nytimes.com.

Newman, B.M. \& Nida, E.A., 1972, A translator's handbook on the Acts of the Apostles, United Bible Societies, London. (Help for Translators XII) 
Olson, R.E., 2009, Finding God in the shack: Seeking truth in a story of evil and redemption, IVP Books, Downers Grove, Ill.

Perrin, D.B., 2007, Studying Christian spirituality, Routledge, New York.

Pervo, R.I., 2006, Dating Acts: Between the evangelists and the apologists, Polebridge, Santa Rosa.

Phicheler, J., 1999, 'Das theologische Anliegen der Paulusrezeption im lukanischer Werk', in J. Verheyden (ed.), The unity of Luke-Acts, pp. 731-744, University Press, Leuven (Bibliotheca Ephemeridum Theologicarum Lovaniensium CXLII).

Rush, W.G., 1980, The Trinitarian controversy, Fortress Press, Philadelphia.

Schleiermacher, F.D.E., [1805] 1843, 'Die Weinachtsfeier: Ein Gespräch', in Sämmtliche Werke, Erste Abtheilung: Zur Theologie, Erster Band, pp. 461-525, G. Reimer, Berlin.

Schleiermacher, F.D.E., [1830] 1928, The Christian faith, 2nd edn., transl. H.R. Mackintosh \& J.S. Stewart, T \& T Clark, Edinburgh.

Schweitzer, A., 1930, Die Mystik des apostels Paulus, Mohr Siebeck, Tübingen.

Steyn, G.J., 1995, Septuagint quotations in the context of the Petrine and Pauline speeches of the Acta Apostolorum, Pharos, Kampen (CBET 12).

Tertullian, [1961], De spectaculis, transl. E. Castorina (ed.), La Nuova Italia, Florence.

Tertullian, [1985], Adversus Praxean, transl. G. Scarput (ed.), Società Editrice Internazionale, Turin.

Tillich, P. [1996] 2007, in A.D. Foster (ed.), The irrelevance and the relevance of the Christian message, Wipf Stock Publishers, Eugene.
Van Aarde, A.G., 2008, "What is "theology" in "public theology" and what is "public" about "public theology"?', HTS Telogiese Studies/Theological Studies 64(3), 1213-1234.

Van Aarde, A.G., 2009a, 'Postsecular spirituality, engaged hermeneutics, and Charles Taylor's notion of hypergoods', HTS Teologiese Studies/Theological Studies 65(1), DOI: 10.4102/ hts.v65i1.166

Van Aarde, A.G., (2009b forthcoming), 'Theological trends in our postsecular age', Verbum et Ecclesia.

Van Kooten, G.H., 2008, Paul's anthropology in context: The image of God, assimilation to God, and tripartite man in ancient Judaism, ancient philosophy and early Christianity, Mohr Siebeck, Tübingen. (WUNT 232)

Van Tilborg, S., 1988, 'Language, meaning, sense and reference: Matthew's passion narrative and Psalm 22', HTS Teologiese Studies/Theological Studies 44(4), 883-908.

Walker, W.O., 2009, 'The "Paulinization" of Peter in the Book of Acts', The Fourth R 22(1), 9-14.

Wikipedia, 2008, s.v. The Shack, viewed 21 June 2009, from http:// www.wikipedia.org/wiki/The-Shack

Windisch, H., [1924] 1970, Der zweite Korintherbrief, hrsg von H. Windisch, 9 Auflage, Vandenhoeck \& Ruprecht, Göttingen.

Wolfe, B., 2008, The shack, a 2007 novel by William P. Young, blog article by Billy Wolfe, December 23, 2008, viewed 21 June 2009, from http://www.ronniewrogers.com/2008/12/29 the shack-a-2007-novel-by-william-p-young-blog-article-bybilly-wolfe-december-23-2008/.

Young, W.P., 2007, The shack, Windblown Media, Newbury Park. 